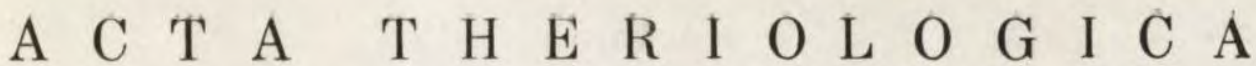 \\ VOL. XII, 14: 223-244. \\ BIAŁOWIEŻA \\ 30.VII.1967
}

Andrzej M Y R C H A

\section{Comparative Studies on the Morphology of the Stomach in the Insectivora}

\author{
With 8 Figs. \& 6 Tables]
}

This study on the morphology of stomachs in 27 species of the Insectivora allows the statement that the general structural plan of the mucous membrane of stomach is similar in all insectivores. Five well- developed glandular areas can be distinguished in all these species: regions of cardiac, fundic and pyloric glands and two transition zones. The relative size of stomach in insectivores is inversely proportional to their body weight, which is probably connected with greater food requirements of smaller species. The enlargement of the relative area of the mucous membrane, achieved by an increase in the area of the region of fundic glands and the elongation of the pyloric portion of the stomach, is observed in smaller insectivores. This mechanism leads to the prolongation of the way and time of the action of proteolytic enzymes on protein food. The absolute weight and size of the shrew stomach undergoes no general winter depression that occurs in these animals. Instead, the stomach index rises with a drop in the ambient temperature, for at that time the body weight of animals decreases. The winter increase in the stomach index of shrews seems to reflect the increased food requirements observed in them at lower temperatures. The reduction of the body size makes it possible for these animals to obtain adequate amounts of food per unit of body weight. The strongest relative development of the stomach is characteristic of the smallest species inhabiting the coldest territories within the range of the Insectivora.

\section{INTRODUCTION}

The structure of different parts of the alimentary canal, particularly that of the stomach, is still relatively poorly known in the Insectivora, as compared with other groups of mammals. F1ower (1872) was the first to publish some data on this subject; he described the external appearance and general structure of the stomach in certain members of the Insectivora. Edelmann (1889) carried out close studies and gave a fairly circumstantial description of the histological structure of the cardiac region of the stomach mucosa in the hedgehog and mole. C a r- 
1 i e r (1893) described the structure of the gastric glands in detail and distinguished three regions in the stomach of Erinaceus europaeus Linnaeus, 1758, namely, a narrow zone of cardiac glands, a large region of fundic glands, and a smaller pyloric region. Nagele (1929) conducted instructive comparative studies of the mucous membrane of the pyloric region of the stomach and the first part of the duodenum in several species of the Insectivora. Lastly, using histological and histochemical methods, Allis on (1948) examined the structure of the stomach very closely in African members of the three families of the order Insectivora. The studies of this author led to the detection of well-developed transition zones between the regions of cardiac, fundic and pyloric glands. The transition zone between the cardiac and fundic regions was very narrow in all cases, whereas the zone between the region of fundic glands and that of pyloric glands turned out to be relatively large and varied from species to species.

Arnbäck-Christie Linde (1907) was the first to note differences in length of the pyloric part between the stomachs of different members of the Insectivora. This authoress reports that Sorex has its terminal part of the stomach much longer than Hydrosorex (=Neomys) and Crocidura. Pernk opf \& L e hner. (1937), too, brought under notice the fact that the tubular pyloric region in Sorex is long in comparison with the corresponding area in Hydrosorex and especially in Suncus. However, it was not until 1948 that Allis on demonstrated the great role played by the varying size of the transition zone between the regions of fundic and pyloric glands in the elongation of the terminal part of the stomach in some insectivores. The glands of this zone are made up, in addition to mucoid cells, of a large number of parietal cells. Out of the species examined by Allis on (l.c.), the pyloric region is the most elongate in the member of the genus Suncus, it is shorter in Eremitalpa and the shortest in Elephantulus.

It will be seen from the foregoing investigations, though they are for the most part incomplete and include only a small number of forms, that there are great specific differences in morphological structure of the mucous membrane between the stomachs of the Insectivora.

The abundant literature on the feeding of insectivores reveals that the basic food of different members of this mammalian order is very similar. Most of the Insectivora consume only protein food of animal origin, composed mainly of invertebrates, which they quite exceptionally complete with small amounts of vegetable food.

However, in spite of their similar nutritional bases the contemporary insectivores show very great differences in many respects. Size and weight of body are such varying characters. Beside very small species, like Sorex minutissimus Z immer$\mathrm{m}$ ann, 1780 or Suncus etruscus Savi, 1822 there are several hundred times as heavy species, e.g., E. europaeus. Between these extreme forms there are a large number of intermediate species. At the same time, great divergencies in the level of metabolism within this group and, what follows, those in food requirements, are associated with these conspicuous differences in body size and weight. It is well known that smaller mammalian species have a higher level of metabolism and greater food requirements. In the Insectivora this relation is still more evident than in other mammals. S. minutissimus, which shows a very high level of metabolism eats $400 \%$ of its body weight in food daily (B la gosklon ov, 1957), Blarina brevicauda (S a y, 1823), whose metabolism is lower, has smaller daily food requirements, ranging from 50 to $70 \%$ of the body weight (B a b cock, 1914; M or r is on et al., 1957), and in Talpa europaea Linna e us, 1758, in which the level of metabolism is still lower, this value amounts to only $28.5-33^{\circ} \%$ of the body weight 
(Fi a u checorne, 1927; Hawkins \& Jewe11, 1962). It should be added that the rate of passage of the foodstuffs through the alimentary canal is as a rule the same in so different forms as Neomys fodiens (P enn ant, 1771) and $T$. europaea (S piridonova, 1949; Kostelecka-M y r cha, 1965).

Vor ontsov (1962) demonstrated the effect of the kind of food eaten on the structure of the alimentary canal in the Muroidea and on this basis he established the ways of nutritional specialization, which, at the same time, are the ways of evolution of this group of rodents. M ezhzherin (1965a, 1965b) put forward the theory that in the Insectivora, especially in the members of the genus Sorex, the nutritional factor was also one of the main evolutionary factors, though in this case not the quality but the quantity of food eaten was decisive. His opinion is based on the phenomenon of a remarkable increase in food requirements of the Insectivora, not excluding the Soricidae, with a drop in the ambient temperature. This increase entails the necessity of acquisition of larger amounts of food under more oppressive environmental conditions. For this reason, according to $\mathrm{Mezhzh}$ erin $(1965 \mathrm{a}, \mathrm{b})$, the tendency towards reduction in body size is a progressive evolutionary trend in this group.

These differences in food requirements and in the quantity of food eaten by insectivores, with their practically uniform nutritional bases, seem to have had an influence on the formation of differences in the structure of the digestive system of particular species. The knowledge of these differences might also throw some light on the rightness of $\mathrm{Mezhzh}$ erin's thesis concerning the role of the nutritional factor in the evolution of these mammals.

Having regard to the foregoing, I investigated the structure of the mucous membrane and the distribution of the particular glandular zones in the part of the alimentary canal which is so important to digestion of flesh food, namely, in the stomach, in many forms of insectivorous mammals. On the basis of the data from literature, I also examined the correlations between the structure of stomach in these species and their level of metabolism and food requirements.

\section{MATERIAL AND METHOD}

A total of 27 species of the three families - Erinaceidae, Talpidae and Soricidae - of the order Insectivora were used for study (Table 1). These specimens came from the collections of the Mammals Research Institute, Polish Academy of Sciences, Białowieża; they were obtained from catches carried out by this Institute in different parts of Poland or by exchange from similar scientific institutions in Canada, Israel, Japan, U.S.A., U.S.S.R. and Zambia ${ }^{1}$ ).

The stomachs of indigenous specimens of the Insectivora were fixed mostly in Bouine's fluid and only exceptionally in formalin. Instead, the material obtained by exchange from other countries was fixed for the most part in formalin and occasionally in ethyl alcohol.

Particular parts of stomachs were embedded in paraffin and sectioned at $5 \mu$.

1) I wish to express my heartfelt thanks to Dr. W. F. H. A n s ell (Fort Jameson), Dr. S. A. Hoslett (Tokyo), Dr. S. H u m ińs ki (Wrocław), Dr. Y. Imaizumi (Tokyo), Dr J. Wahrman (Jerusalem) and Dr. P. M. Youngman (Ottawa) for their help with the collection of material. 
Sections were stained with hematoxylin-eosin by the Mallory method or with hematoxylin-mucicarmine-aurantia and mounted in Canada balsam.

The area of the particular glandular zones of the mucous membrane was measured with a Zeiss eyepiece micrometer (Okularschraubenmikrometer) and their extent plotted on the drawings made beforehand to a scale of $10: 1$ and showing sections of the stomachs in a plane passing through both their curvatures. On the basis of these diagrams the area of particular glandular zones was calculated by

Table 1.

Material examined.

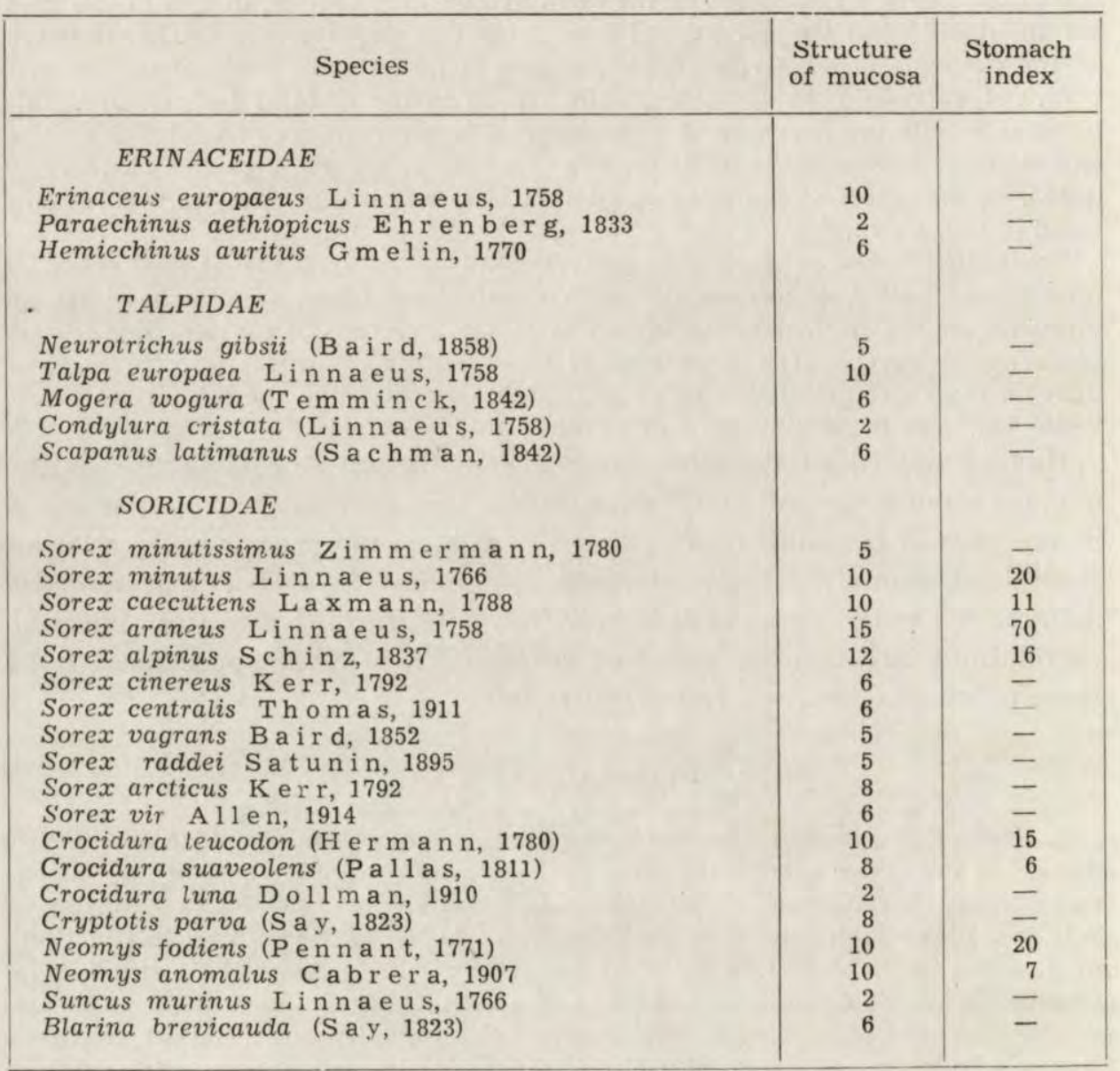

the method of planimetry and the results obtained were divided by 10 . The proportion of particular zones to the total area of the section of stomach was calculated for each species and, for some of them, also the area of these zones per unit of body weight. This last index could not be calculated for all the Insectivora under study, because most of the specimens obtained from abroad had not been weighed after catching. The degree of elongation of the stomach was calculated by comparing the lengths of particular zones expressed in centimetres with their relation to the total 
length of this organ. The degree of stomach elongation in different species was also presented as a length ratio of stomach to animal body.

Stomach indices were determined for indigenous members of the family Soricidae in this manner that the weight of these organs was expressed in percentages of the body weight.

Seasonal and age variation in this index was examined in the case of $S$. araneus, which was represented in very large numbers in the material used for study. Material fixed in formalin was applied for this purpose. Stomachs, removed from the bodies, were washed carefully under running water, dried in cellulose tissue and next weighed to an accuracy of $0.001 \mathrm{~g}$. Gross body weights obtained prior to fixation were used for the calculation of stomach indices. The index, calculated in this manner, does not express exact values, because it is charged with an error caused by the action of the fixative on the stomach. Since, however, the fixative was the same solution of formalin in all these cases, the values calculated seem to reflect the actual differences between the relative weights of stcmachs of various species of the Insectivora.

The results obtained were put to a statistical analysis. The sets of data were characterized by calculating confidence intervals based on the variable $t$. The significance of the differences between the indices obtained for different species was examined by Student's $t$ test for differences between the means from two independent groups.

\section{RESULTS}

\section{Shape of stomach}

The shape of the stomach in the insectivores under study shows great specific differences. The stomach of the Erinaceidae has the shape of a purse with well-developed curvatures, and in this they resemble most of the Chiroptera, Carnivora and Primates (Fig. 1). The pyloric part of this organ is bent parallel to the oesophagus, and the pylorus itself lies higher than the cardia. A distinctive character of the stomach of Erinaceidae is also the far greater thickness of its walls than in the other families, which is due to a very strong development of all the layers of its muscular tissue.

In other groups of the Insectivora the shape of stomach varies much from the form represented by the hedgehogs. A conspicuous elongation of the pyloric portion of the stomach is evident in all the species of Talpidae (Fig. 2) and Soricidae (Fig. 3-6) examined. However, in most species of the Talpidae there is also a bend (though smaller than in the Erinaceidae) in this region of stomach in a direction parallel to the oesophagus, whereas in all the Soricidae the pyloric part is very long and entirely unbent, which in many species entails the almost complete disappearance of the lesser curvature. The stomach loses its shape of a purse, and in the cases of the greatest elongation of the pyloric portion, observed in the members of the genus Sorex (Figs. 3 and 4), it assumes 


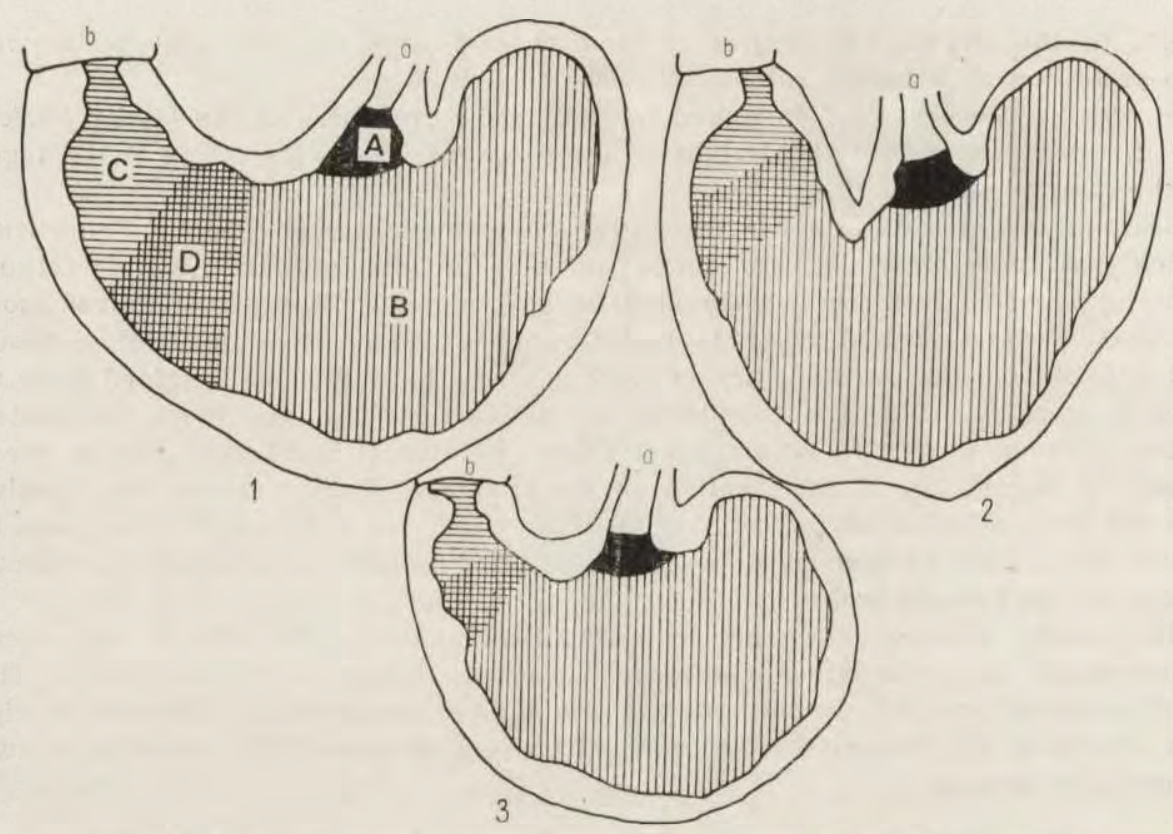

Fig. 1. A diagram of the structure of stomachs in the Erinaceidae.

1 - Erinaceus europaeus, 2 - Paraechinus aethiopicus, 3 - Hemiechinus auritus. Magnified $2.5 \times$. a - oesophagus, b - duodenum, A - cardiac glands, B - fundic glands, C - pyloric glands, D - transition zone.

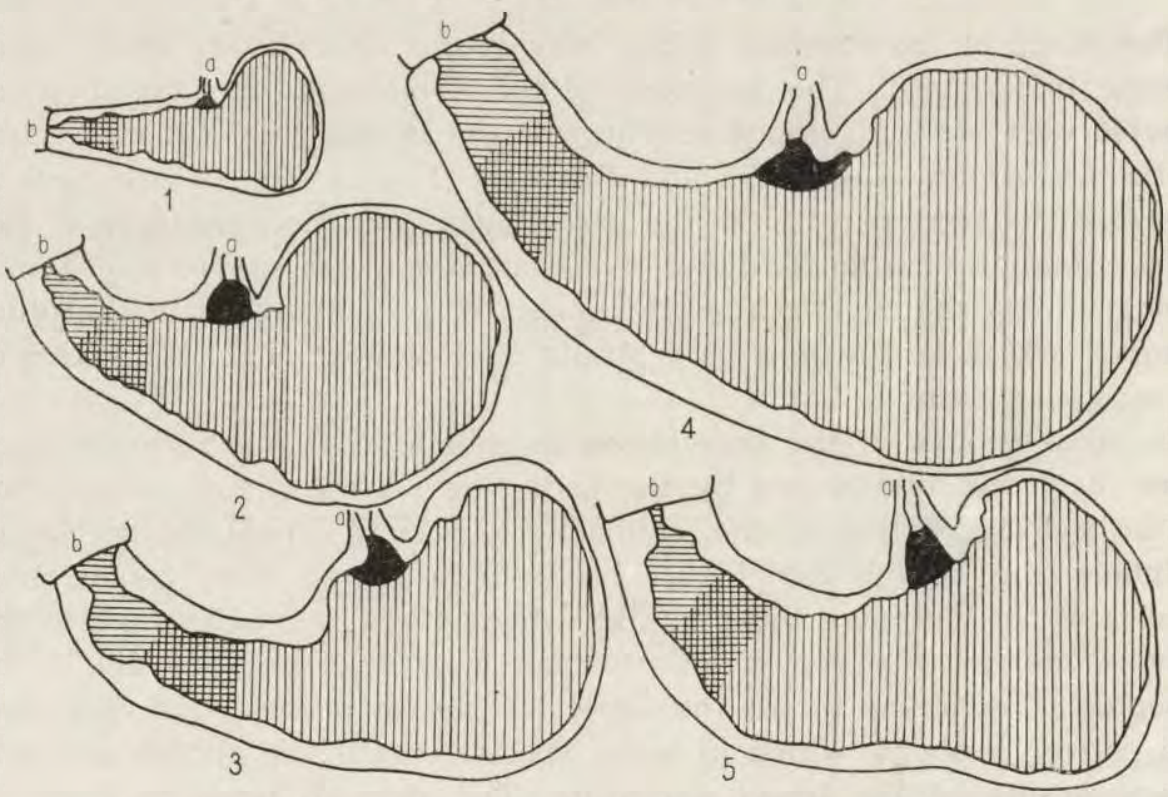

Fig. 2. A diagram of the structure of stomachs in the Talpidae.

1 - Neurotrichus gibsii, 2 - Talpa europaea, 3 - Mogera wogura, 4 - Condylura cristata, 5 - Scapanus latimanus. Magnified $2.5 \times$. Designations as in Fig. 1. 

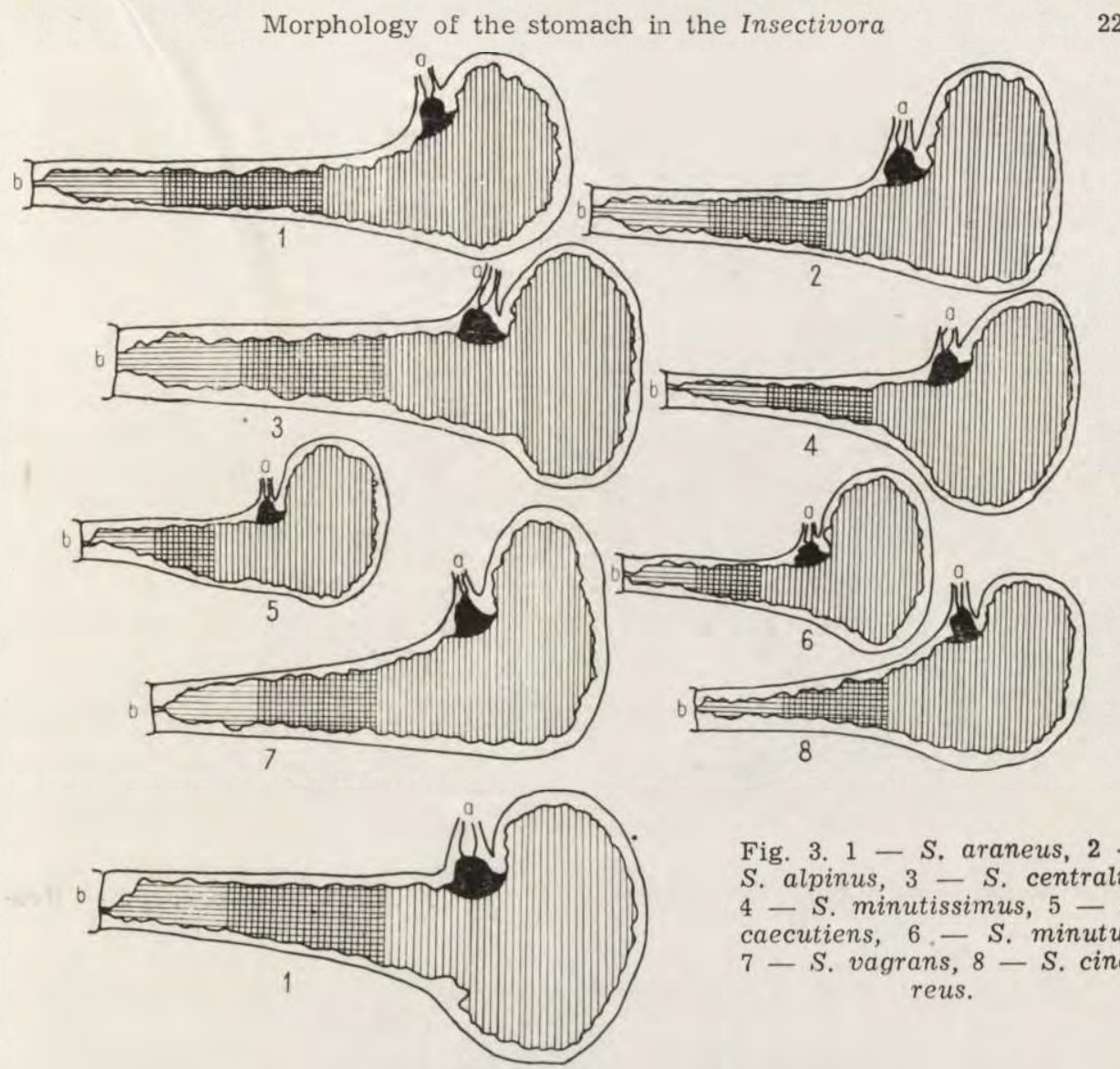

Fig. 3. $1-S$, araneus, $2-$ $S$. alpinus, $3-S$. centralis, $4-S$. minutissimus, $5-S$. caecutiens, $6-S$. minutus, 7 - S. vagrans, $8-$ S. cinereus.

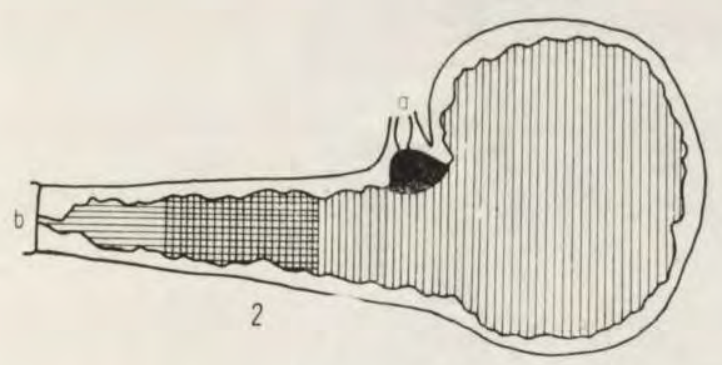

Fig. 4. $1-S$. raddei, $2-S$. arcticus, $3-S$. vir.

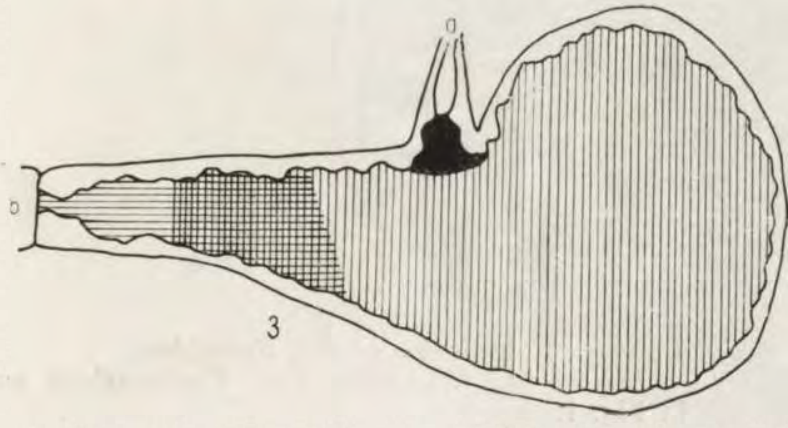

Fig. 3-4. A diagram of the structure of stomachs in the Soricidae. Magnified 5×. Designations as in Fig. 1. 


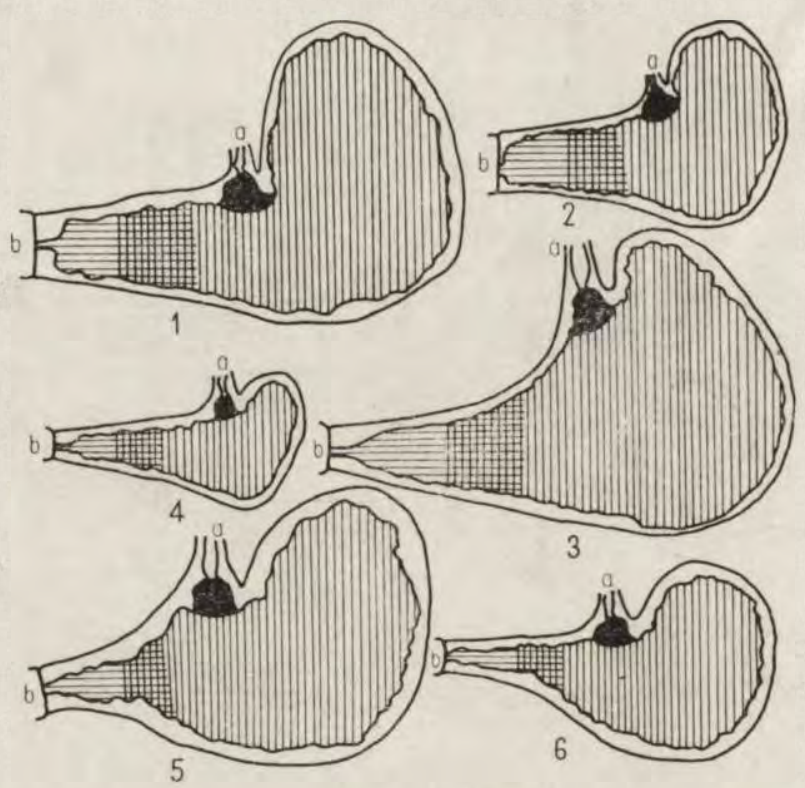

Fig. 5. A diagram of the structure of stomachs in the Soricidae.

1 - Crocidura leucodon, $2-$ C. suaveolens, $3-$ C. luna, $4-$ C. parva, $5-\mathrm{Neo-}$ mys fodiens, $6-N$. anomalus. Magnified $5 \times$. Designations as in Fig. 1.
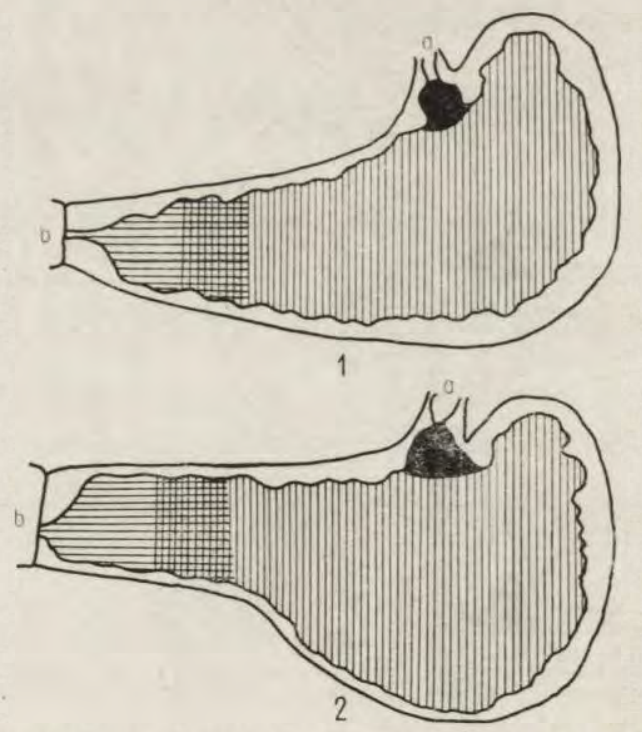

Fig. 6. A diagram of the structure of stomachs of the Soricidae.

1 - Suncus murinus, 2 - Blarina brevicauda. Magnified $5 \times$. Designations as in Fig. 1. 
the typical shape of the letter J. Such a J-shaped stomach can also be observed in the species which belong to the other genera of the Soricidae, but in these the pyloric region is not so strongly elongated as in the species of the genus Sorex. The greatest shortening of this region occurs in the members of the genus Neomys (Fig. 5).

\section{Histological structure of mucous membrane}

Histological examination of the structure of the mucous membrane in the stomach of the Insectivora showed the existence of well-developed regions containing different kinds of digestive glands in all the species under study; in structure these regions resemble the corresponding areas in other groups of mammals. In the region of the cardia, in the part bordering upon the oesophagus, there is a small area of cardiac glands. The region of fundic glands covers the whole fundus of the stomach and extends, both on the ventral and the dorsal side, over a greater part of the great curvature and the first part of the lesser curvature. The third typical region, that of pyloric glands, lies in the neighbourhood of the pylorus. The occurrence of two transition zones situated between these three regions is very characteristic of the histological structure of the mucous membrane in the stomachs of all the species of insectivorous mammals examined. The glands of these zones are marked by the presence of parietal cells, which occur among the mucoid cells all over the bodies and necks of glands. They do not, however, contain chief cells.

Planimetry of the projections of stomachs made it possible to find that the area of the region of fundic glands was the largest in all our cases (Table 2). The transition zone between the region of fundic glands and that of pyloric glands is second largest, though it is several times smaller than the previous area. The region of pyloric glands, lying behind this last zone, covers a still smaller area in projections. The group of cardiac glands occupies a relatively small area of the mucous membrane, but the transition zone neighbouring upon it is the smallest. This zone is so narrow that it was impossible to mark it on the 10:1-scale drawings.

\section{Surface area of mucous membrane}

A comparison of the results presented in Tables 2 shows that the areas occupied by the particular glandular regions, expressed as percentages of the total area of the mucous membrane are different in different species. In general, this index for the region of fundic glands reaches the highest values in the members of the Erinaceidae and Talpidae and decreases in the members of particular genera of the family Soricidae to show the lowest values in the species of the genus Sorex. E. europaeus, 
in which the region in question occupies the smallest proportion of the stomach surface, is the only exception. Analysing the data calculated for the regions of pyloric and transitional glands in the pyloric portion of the stomach, one can observe an inverse relation. The relative surface area of these regions reaches the highest values in the members of the

Table 2.

Area indices of the projections of stomachs in the species of Insectivora examined.

\begin{tabular}{|c|c|c|c|c|c|c|c|c|c|}
\hline \multirow[t]{2}{*}{ Species } & \multicolumn{2}{|c|}{$\begin{array}{l}\text { Fundic } \\
\text { glands }\end{array}$} & \multicolumn{2}{|c|}{$\begin{array}{c}\text { Transition } \\
\text { zone }\end{array}$} & \multicolumn{2}{|c|}{$\begin{array}{l}\text { Pyloric } \\
\text { glands }\end{array}$} & \multicolumn{2}{|c|}{$\begin{array}{l}\text { Cardiac } \\
\text { glands }\end{array}$} & \multirow{2}{*}{$\begin{array}{l}\mathrm{Mu} \\
\mathrm{cosa} \\
\mathrm{cm}^{2}\end{array}$} \\
\hline & $\mathrm{cm}^{2}$ & $\stackrel{o}{o}$ & $\mathrm{~cm}^{2}$ & $\%$ & $\mathrm{~cm}^{2}$ & $\stackrel{o}{o}$ & $\mathrm{~cm}^{2}$ & $\stackrel{0}{o}$ & \\
\hline \multicolumn{10}{|l|}{ TALPIDAE } \\
\hline Neurotrichus gibsii & 3.14 & 89.2 & 0.20 & 5.7 & 0.14 & 4.0 & 0.04 & 1.1 & 3.52 \\
\hline Talpa europaea & 11.14 & 86.6 & 0.85 & 6.6 & 0.54 & 4.2 & 0.33 & 2.6 & 12.86 \\
\hline Mogera wogura & 12.00 & 83.6 & 1.14 & 7.9 & 0.80 & 56 & 0.42 & 2.9 & 14.36 \\
\hline Condylura cristata & 21.84 & 84.5 & 1.74 & 6.7 & 1.66 & 64 & 0.60 & 2.3 & 25.84 \\
\hline Scapanus latimanus & 13.64 & 84.9 & 1.22 & 7.6 & 0.80 & 5.0 & 0.40 & 2.5 & 16.06 \\
\hline \multicolumn{10}{|l|}{ ERINACEIDAE } \\
\hline Erinaceus europaeus & 13.50 & 64.5 & 3.68 & 17.6 & 3.00 & 14.3 & 0.74 & 3.5 & 20.92 \\
\hline Paraechinus aethiopicus & 13.54 & 79.5 & 1.76 & 10.3 & 1.10 & 6.5 & 0.62 & 3.6 & 17.02 \\
\hline Hemiechinus auritus & 13.20 & 86.5 & 0.84 & 5.5 & 0.82 & 5.4 & 0.40 & 2.6 & 15.26 \\
\hline \multicolumn{10}{|l|}{ SORICIDAE } \\
\hline Sorex minutissimus & 2.94 & 82.6 & 0.35 & 9.8 & 0.18 & 5.1 & 0.09 & 2.5 & 3.56 \\
\hline Sorex minutus & 1.81 & 79.7 & 0.25 & 11.0 & 0.16 & 6.1 & 0.05 & 2.2 & 227 \\
\hline Sorex caecutiens & 1.92 & 78.4 & 0.30 & 12.2 & 0.16 & 6.5 & 0.07 & 2.9 & 2.45 \\
\hline Sorex araneus & 2.92 & 71.6 & 0.69 & 16.9 & 0.37 & 9.1 & 0.10 & 2.4 & 4.08 \\
\hline Sorex alpinus & 3.30 & 75.9 & 0.56 & 12.9 & 0.37 & 8.5 & 0.12 & 2.8 & 4.35 \\
\hline Sorex cinereus & 3.08 & 81.5 & 042 & 11.1 & 0.20 & 5.3 & 0.08 & 2.1 & 3.78 \\
\hline Sorex centralis & 3.82 & 69.2 & 0.98 & 17.7 & 0.60 & 10.9 & 0.12 & 2.2 & 5.52 \\
\hline Sorex vagrans & 3.37 & 72.0 & 0.73 & 15.6 & 0.46 & 9.8 & 0.12 & 2.6 & 4.68 \\
\hline Sorex raddei & 4.32 & 71.0 & 1.05 & 17.3 & 0.53 & 87 & 0.18 & 30 & 6.08 \\
\hline Sorex arcticus & 7.13 & 81.8 & 0.98 & 11.2 & 0.43 & 4.9 & 0.18 & 2.1 & 8.72 \\
\hline Sorex vir & 8.30 & 79.0 & 1.37 & 13.0 & 0.59 & 5.6 & 0.24 & 2.3 & 10.50 \\
\hline Cryptotis parva & 0.93 & 75.6 & 0.16 & 13.0 & 0.11 & 8.9 & 0.03 & 2.4 & 1.23 \\
\hline Crocidura suaveolens & 1.96 & 73.1 & 0.31 & 11.6 & 0.32 & 11.9 & 0.09 & 3.4 & 2.68 \\
\hline Crocidura leucodon & 4.54 & 81.2 & 0.56 & 10.0 & 0.36 & 6.4 & 0.13 & 2.3 & 5.59 \\
\hline Crocidura luna & 5.05 & 81.0 & 0.62 & 9.9 & 0.42 & 6.7 & 0.14 & 2.2 & 6.23 \\
\hline Blarina brevicauda & 6.53 & 77.9 & 0.73 & 8.8 & 0.84 & 10.0 & 1.28 & 3.3 & 8.38 \\
\hline Suncus murinus & 5.98 & 81.7 & 0.60 & 8.2 & 0.58 & 7.9 & 0.16 & 2.3 & 7.32 \\
\hline Neomys anomalus & 2.27 & 86.6 & 0.16 & 6.1 & 0.12 & 4.6 & 0.07 & 2.7 & 2.62 \\
\hline Neomys fodiens & 3.97 & 87.4 & 0.25 & 5.5 & 0.19 & 4.2 & 0.13 & 2.9 & 454 \\
\hline
\end{tabular}

genus Sorex, which is probably connected with the elongated shape of the stomachs in the Soricidae. It must be added that in both the species of water-shrews, which have the shortest pyloric portion of the stomach of all the Soricidae, the value of this index is only somewhat higher than a half of the corresponding value in the members of Sorex. The proportion of the surface of the mucous membrane occupied by the region of 
cardiac glands is as a rule very similar in all the species of Insectivora examined.

The specific variation of the indices which characterize the size of the surface of the mucous membrane and its particular regions coming to a unit of body weight, appears interesting. Generally speaking, the values

Table 3.

Relative area of mucous membrane per unit of body weight in the Insectivora.

\begin{tabular}{|c|c|c|c|c|c|}
\hline \multirow[b]{2}{*}{ Species } & \multicolumn{5}{|c|}{ Surface, $\mathrm{cm}^{2} /$ body weight, $\mathrm{g}$} \\
\hline & $\begin{array}{l}\text { Fundic } \\
\text { glands }\end{array}$ & $\begin{array}{c}\text { Transition } \\
\text { zone }\end{array}$ & $\begin{array}{l}\text { Pyloric } \\
\text { glands }\end{array}$ & $\begin{array}{l}\text { Cardiac } \\
\text { glands }\end{array}$ & Mucosa \\
\hline Sorex minutissimus & 1.630 & 0.194 & 0.100 & 0.050 & 1.980 \\
\hline Sorex minutus & 0.670 & 0.092 & 0.059 & 0.018 & 0.841 \\
\hline Sorex araneus & 0.551 & 0.130 & 0.070 & 0.019 & 0.770 \\
\hline Sorex vir & 0.602 & 0.089 & 0.054 & 0.020 & 0.765 \\
\hline Sorex alpinus & 0.545 & 0.092 & 0.061 & 0020 & 0.719 \\
\hline Sorex caecutiens & 0.548 & 0.086 & 0.046 & 0020 & 0.700 \\
\hline Sorex centralis & 0.494 & 0.075 & 0.046 & 0.009 & 0.624 \\
\hline Crocidura suaveolens & 0.560 & 0.089 & 0.091 & 0.026 & 0.766 \\
\hline Crocidura leucodon & 0.593 & 0.073 & 0.047 & 0.017 & 0.730 \\
\hline Neomys anomalus & 0.320 & 0.015 & 0.012 & 0.007 & 0354 \\
\hline Neomys fodiens & 0.331 & 0021 & 0016 & 0.011 & 0379 \\
\hline Talpa europaea & 0.223 & 0.017 & 0.011 & 0.007 & 0.258 \\
\hline Erinaceus europaeus & 0.018 & 0.005 & 0.004 & 0.001 & 0.028 \\
\hline
\end{tabular}

of these indices are inversely proportional to the body size of insectivores and reach the highest level in S. minutissimus, whereas the lowest level was found in E. europaeus (Table 3).

\section{Degree of elongation of stomachs}

Great specific variation was also found in the indices illustrating the degree of elongation of the stomach in the insectivorous mammals under study (Table 4). It was impossible and, at the same time, purposeless to calculate this index for the species of the family Erinaceidae on account of the purse-like shape of their stomachs without any signs of elongation of the pyloric portion. As to the other insectivores, the ratio of stomach length to body length in the members of the family Soricidae shows the greatest differences. Its value is the highest in the species of the genus Sorex and the lowest in $N$. fodiens and $N$. anomalus. An analysis of the percentage relation of the glandular regions to the total length of the stomach revealed that owing to the elongation of this organ in shrews there occurs a partial increase in area of its region of pyloric glands and a remarkable increase of the adjoining transition zone. The ratio of stomach length to body length in the Talpidae examined is exceptionally 
great and corresponds approximately to the value of this index in the members of the genus Sorex. Unlike the situation observed in shrews, in this case the elongation of the stomach does not result in an increase

Table 4.

Degrees of elongation of stomachs in the Insectivorc examined.

\begin{tabular}{|c|c|c|c|c|c|c|c|c|}
\hline \multirow[t]{2}{*}{ Species } & \multicolumn{2}{|c|}{$\begin{array}{l}\text { Fundic } \\
\text { glands }\end{array}$} & \multicolumn{2}{|c|}{$\begin{array}{c}\text { Transition } \\
\text { zone }\end{array}$} & \multicolumn{2}{|c|}{$\begin{array}{l}\text { Pyloric } \\
\text { glands }\end{array}$} & \multirow[t]{2}{*}{ Stomach } & \multirow{2}{*}{$\begin{array}{c}\text { Head } \& \text { body } \\
\text { length of } \\
\text { stomach }\end{array}$} \\
\hline & $\mathrm{cm}$ & 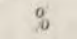 & $\mathrm{cm}$ & $\stackrel{0}{o}$ & $\mathrm{~cm}$ & $\underset{0}{0}$ & & \\
\hline Sorex minutissimus & 0.67 & 48.5 & 0.37 & 26.8 & 0.34 & 24.6 & 1.38 & 0.33 \\
\hline Sorex minutus & 0.56 & 53.8 & 0.23 & 22.1 & 0.25 & 24.0 & 1.04 & 029 \\
\hline Sorex araneus & 0.80 & 44.7 & 0.54 & 30.2 & 0.45 & 25.1 & 1.79 & 0.28 \\
\hline Sorex raddei & 0.88 & 47.8 & 0.52 & 28.3 & 0.44 & 23.9 & 1.84 & 0.28 \\
\hline Sorex centralis & 0.86 & 48.3 & 0.50 & 281 & 0.42 & 23.6 & 1.78 & 0.27 \\
\hline Sorex vagrans & 0.73 & 48.0 & 0.39 & 25.6 & 0.40 & 26.3 & 1.52 & 0.27 \\
\hline Sorex caecutiens & 0.56 & 54.9 & 0.21 & 20.6 & 0.25 & 245 & 1.02 & 0.26 \\
\hline Sorex cinereus & 0.62 & 48.4 & 0.33 & 25.8 & 0.33 & 25.8 & 1.28 & 0.26 \\
\hline Sorex alpinus & 0.76 & 48.4 & 0.40 & 25.5 & 0.41 & 26.1 & 1.57 & 0.24 \\
\hline Sorex arcticus & 1.15 & 56.9 & 0.46 & 22.8 & 0.41 & 20.3 & 2.02 & 023 \\
\hline Sorex vir & 1.41 & 60.2 & 0.49 & 20.9 & 0.44 & 18.8 & 2.34 & 0.23 \\
\hline Crocidura suaveolens & 0.47 & 54.0 & 0.17 & 19.5 & 0.23 & 26.5 & 0.87 & 0.16 \\
\hline Crocidurale leucodon & 080 & 62.0 & 0.23 & 17.8 & 0.26 & 20.1 & 129 & 0.18 \\
\hline Crocidura luna & 0.83 & 58.4 & 0.24 & 16.9 & 0.37 & 26.0 & 1.42 & - \\
\hline Neomys anomalus & 0.61 & 58.6 & 0.16 & 16.4 & 0.27 & 26.0 & 1.04 & 0.14 \\
\hline Neomys fodiens & 0.80 & 68.4 & 0.15 & 12.8 & 0.22 & 18.8 & 1.17 & 0.14 \\
\hline Blarina brevicauda & 1.12 & 64.4 & 0.24 & 13.8 & 0.38 & 21.8 & 1.74 & 0.15 \\
\hline Suncus murinus & 1.08 & 64.7 & 0.20 & 12.0 & 0.39 & 233 & 1.67 & - \\
\hline Cryptotis parva & 0.38 & 52.8 & 0.14 & 19.4 & 0.20 & 27.8 & 0.72 & 0.17 \\
\hline Talpa europaea & 2.10 & 68.6 & 0.42 & 13.7 & 0.54 & 17.6 & 3.06 & 0.24 \\
\hline Neurotrichus gibsii & 1.26 & 73.2 & 0.20 & 11.6 & 0.26 & 15.1 & 1.72 & 0.15 \\
\hline Condylura cristata & 3.68 & 745 & 0.56 & 11.3 & 0.70 & 14.2 & 4.94 & 0.25 \\
\hline Scapanus latimanus & 2.52 & 71.2 & 042 & 11.9 & 0.60 & 16.9 & 3.54 & 0.22 \\
\hline Mogera wogura & 2.26 & 64.2 & 0.60 & 17.0 & 0.66 & 18.7 & 3.52 & 0.21 \\
\hline
\end{tabular}

Table 5.

A comparison of stomach indices in some species of Soricidae.

\begin{tabular}{|l|c|c|c|}
\hline \multicolumn{1}{|c|}{ Species } & $\begin{array}{c}\text { Body } \\
\text { weight }\end{array}$ & $\begin{array}{c}\text { Stomach } \\
\text { weight }\end{array}$ & $\begin{array}{c}\text { Stomach } \\
\text { index }\end{array}$ \\
\hline Sorex minutus & $3.750 \pm 0.4$ & $0.046 \pm 0.007$ & $1.32 \pm 0.07$ \\
Sorex caecutiens & $4.750 \pm 0.8$ & $0.055 \pm 0.001$ & $1.16 \pm 0.10$ \\
Sorex araneus & $7.700 \pm 0.6$ & $0.082 \pm 0.002$ & $1.06 \pm 0.06$ \\
Sorex alpinus & $7.650 \pm 0.8$ & $0.072 \pm 0.009$ & $0.95 \pm 0.09$ \\
Crocidura leucodon & $7.950 \pm 0.7$ & $0.071 \pm 0.008$ & $0.91 \pm 0.09$ \\
Crocidura suaveolens & $5.400 \pm 0.7$ & $0.033 \pm 0.018$ & $0.61 \pm 0.11$ \\
Neomys anomalus & $9.930 \pm 1.1$ & $0.041 \pm 0.003$ & $0.41 \pm 0.09$ \\
Neomys fodiens & $12.750 \pm 1.4$ & $0.069 \pm 0.005$ & $0.56 \pm 0.05$ \\
\hline
\end{tabular}

of the area of pyloric glands and of the transition zone in relation to the total length of stomach. In the Talpidae the relative length of these regions is smaller than in the members of any genus of the Soricidae. 


\section{Stomach index}

Stomach indices calculated for the native Soricidae (Table 5) show that in Sorex this organ has the greatest relative weight. In the species of the genus Crocidura this index is lower and in Neomys its value comes to less than a half of that in Sorex (differences are statistically significant).

Table 6.

Seasonal and age variation of the stomach index in Sorex araneus.

\begin{tabular}{|l|c|c|c|c|}
\hline \multicolumn{1}{|c|}{ Season — age } & N & $\begin{array}{c}\text { Body } \\
\text { weight }\end{array}$ & $\begin{array}{c}\text { Stomach } \\
\text { weight }\end{array}$ & $\begin{array}{c}\text { Stomach } \\
\text { index }\end{array}$ \\
\hline Summer - young adult & 20 & $6.700 \pm 0.3$ & $0.081 \pm 0.003$ & $1.20 \pm 0.06$ \\
Winter - young adult & 30 & $\mathbf{5 . 6 0 0 \pm 0 . 5}$ & $0.079 \pm 0.004$ & $1.36 \pm 0.02$ \\
Summer - old adult & 20 & $10.600 \pm 0.6$ & $0.085 \pm 0.003$ & $0.71 \pm 0.08$ \\
\hline
\end{tabular}

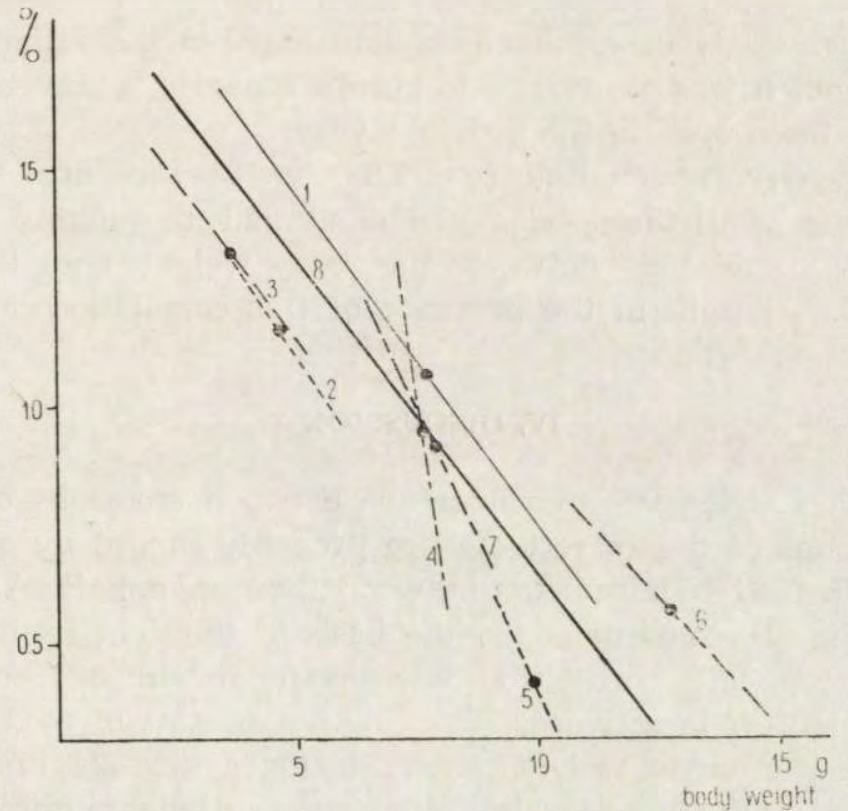

. Fig. 7. Regression lines showing the correlation between the stomach index and the body weight in the Soricidae.

1 - Sorex araneus, 2 - Sorex minutus, 3 - Sorex caecutiens, 4 - Sorex alpinus, 5 - Crocidura leucodon, 6 - Neomys fodiens, 7 - Neomys anomalus, 8 - all Soricidae.

In the four species of the genus Sorex included in this study the stomach indices are inversely proportional to the mean body weights of these animals. The greatest relative weight of stomach was found in $S$. minutus, it was smaller in $S$. caecutiens and the smallest in $S$. araneus and $S$. alpinus. These differences are also statistically significant. 
The value of the stomach index in $S$. araneus undergoes great seasonal and age variation (Table 6). In the winter the relative weight of this organ is remarkably larger than in the summer. Young summer shrews have higher values of the index than the specimens born in the previous year examined at the same time. In both these cases the differences are statistically significant. It is noteworthy that the direct cause of these fluctuations of the stomach index in $S$. araneus are the changes in the body weight of animals, for the absolute weight of the stomach undergoes no changes.

The regression lines drawn for 7 species (Fig. 7) illustrate the correlation between the relative weight of stomachs and the body weight of particular specimens very clearly. An increase in the stomach index with the simultaneous reduction of the body weight can be observed in all these cases. This correlation is least distinct in S. alpinus, which is probably caused by the fact that the material used for investigations was composed exclusively of specimens caught early in the summer and, on the other hand, it was too scanty to permit separate treatment of young animals and those born in the previous year.

The common regression line $(y=1.96-0.133 x)$ constructed for the representatives of all the species examined and the highly significant coefficient of correlation between the body weight and the stomach index $(r=0.867)$ confirm the presence of this correlation in the Sor:cidae.

\section{DISCUSSION}

The differences in size and structure between stomachs observed in different groups of the Insectivora are probably caused by quantitative differences in food requirements between these mammals. A hypothetcal curve (Fig. 8), constructed on the basis of the data from literature, shows the existence of correlation between the amount of food eaten and the body weight of insectivores. The relative amount of food (expressed in percertages of body weight) eaten during a day (24 hrs) increases with the reduction in body size, this increase being unproportionally great in the species with a body weight smaller than $5 \mathrm{~g}$ as compared with that found in larger species. At the same time, the smaller species have larger and heavier stomachs relative to their size. This relation is particularly well seen in the members of the family Soricidae. The index expressing the area of the mucous membrane per unit of body weight reaches the highest values in the species of the genus Sorex; these values are somewhat smaller in the genus Crocidura and the smallest in both the species of Neomys included in this study. The values of stomach indices are distributed analogically. Hence it follows that the insectivo- 
res which consume more food during the day have a larger digestive area of the mucous membrane of the stomach. This is only natural, for they must digest larger amounts of food similar in quality in the same period of time.

The necessary increase in the size of stomach with the increase of the amount of food eaten proceeds in two ways in the Insectivora examined. On the one hand, there occurs a very conspicuous growth in the volume and, what follows, in the surface of the portion of this organ occupied

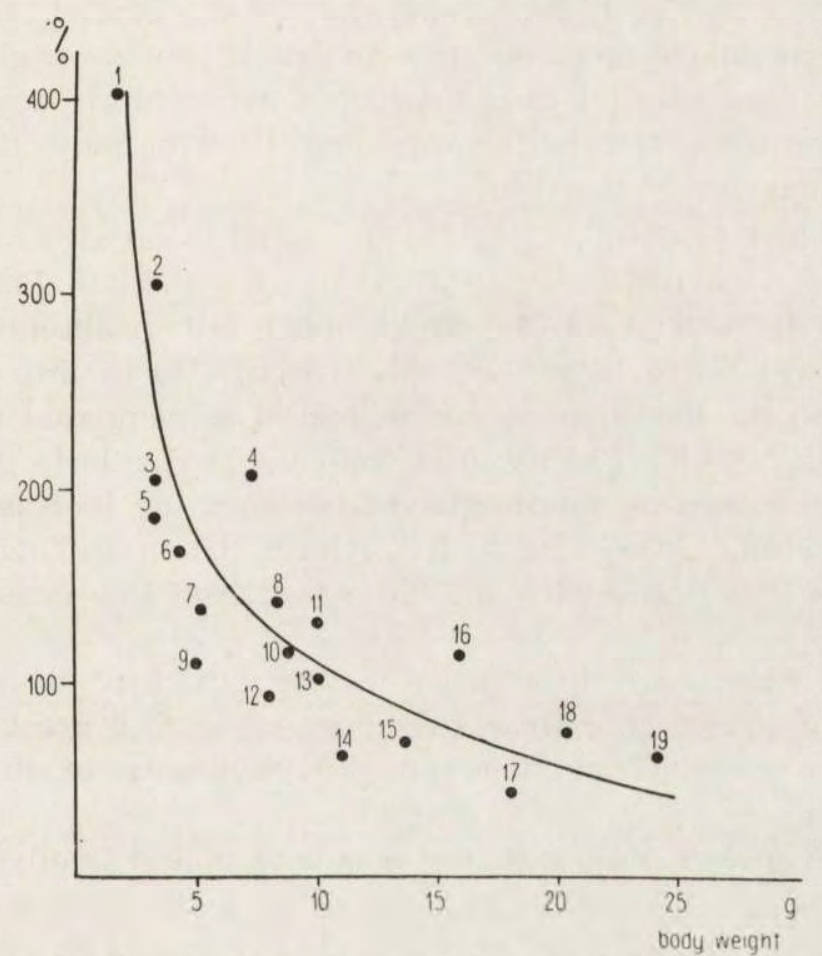

Fig. 8. A curve showing the dependence of the magnitude of food requirements on the body weight in the Soricidae.

1 - Sorex minutissimus, 2, 5- Sorex cinereus, 3, 6 - Sorex minutus, 4, 9, 11, 15 Sorex araneus, 13 - Sorex palustris, 7 - Crocidura suaveolens, 8 - Cryptotis floridana, 10 - Diplomesodon pulchellum, 12 - Crocidura cassiteridum, 14, 16, 18 Neomys fodiens, 17,19 - Blarina brevicauda. (1, 4, 18 - Bl a gos k 1 on o v, 1957; 2 - Blos s om, 1932; 3, 7, 9, 14 - Tupikova, $1949 ; 5,19-$ Morris on et al., $1957 ; 6,11,12,16$ - Hawkins \& Jewel1, 1962; 8 - Springer, 1937; 10 Heptner, $1939 ; 13-$ C onn aw ay, $1952 ; 15-$ Rörig, $1905 ; 17-$ Ha milton, 1930

by fundic glands (in relation to body size). On the other hand, if this growth is not sufficient, the pyloric portion undergoes a strong elongation, which is particularly well seen in the genus Sorex. The growth in length of the pyloric region in Soricidae brings about a linear and superficial increase, especially, of transitional zone between the fundic and 
pyloric glandular regions and a partial increase of the area of pyloric glands. This is particularly important, if we take into account the fact that the insectivores feed mainly on protein food and only in exceptional cases and quite reluctantly eat, e.g., old larvae of cockchafers, which contain large amounts of fat (Skoczeń, 1966). Such a considerable elongation of the pyloric portion, as can be observed in the genus Sorex, in comparison with, e.g., the species of the genus Neomys, leads to an increase of the way along which large quantities of protein food are subject to the action of digestive enzymes. On the other hand, the linear and superficial enlargement of the transition zone of glands, which contain numerous parietal cells producing hydrochloric acid is responsible for the prolongation of the way and time of the action of active proteolytic enzymes on the food.

Moles eat less food in relation to the weight and size of their body than the Soricidae (H is aw, 1923; Hauchecorne, 1927; Christian, 1950; Hawkins \& J e we 11, 1962), but in absolute units this quantity is still fairly large. For this reason, also in this case the digestive surface of the stomach has increased as compared with that in the Erinaceidae, which has resulted from the particularly great growth of the area occupied by fundic glands. However, no increase in area of the transition zone adjoinning to the pyloric glands, so characteristic of the Soricidae and especially of the species of the genus Sorex, is observable.

The similarities and differences in the structure of stomachs of contemporary insectivores presented above agree to a great extent with the generally accepted opinions on the phylogeny of this group of animals.

Out of the species discussed, the members of the family Erinaceidae have the most primitive shape of stomach. In shape their stomach much resembles this organ in the Tupaidae. Allis on (1948) described the stomach of Elephantulus (Macroscelididae), almost identical with the previous ones in respect of shape and structure. These data corroborate the views of Simpson (1931) and Butler (1948), based on the analysis of fossil material, that the Tupaidae and Macroscelididae are closely related to the Erinaceidae and that these groups went away from the common stem of insectivores early. The Erinaceidae are the most specialized of these families. Their specialization is also reflected by the structure of the stomach, in which it is represented by a very strong development of all the layers of muscular tissue.

The structure of the stomach in the members of Talpidae examined combines the characters of stomachs both of the Erinaceidae and the Soricidae. On the one hand, moles, like the Soricidae, show a strong elongation 
of the pyloric portion of this organ; on the other hand, however, the bent shape of this portion and the distribution of digestive glands in the mucous membrane make moles' stomachs similar to that of the Erinaceidae. The stomach of an American member of the Talpidae, N. gibsii, is mariked by its intermediate structure, for its shape is typical of the Soricidae, whereas the ranges of the particular glandular zones are the same as in other moles. These data seem to support the supposition about the origin of the contemporary Talpidae and Soricidae from a common stem, the more so, because this opinion is based not only on analyses of remains of bones (the presence of characters both of primitive shrews and of moles in the dentition of the Nyctitheridae, the ancestors of modern moles) but also on the fact that the contemporary Talpidae of the genera Urotrichus and Neurotrichus have an intermediate position between shrews and moles in respect of morphology (Thenius \& Hofer, 1960).

All the species which represent the family Soricidae in this study are characterized by a very similar shape of stomach and structural plan of its mucous membrane. In spite of these convergencies they also show fairly great differences, namely, the ununiform elongation of the pyloric portion of stomach and the varying area of the region of pyloric glands and the adjoining transition zone. The members of the genus Sorex have the most conspicuous elongation of the pylorus, whereas the poorest development of this part of stomach has been found in the genus Neomys, which, according to Thenius \& H of er (1960), was the first to branch of from the common stem of the Soricidae. The species which belong to the genera Crocidura, Suncus and Blarina exhibit an intermediate structure of stomach between the two groups mentioned above. The stomachs of Crocidura resemble the form represented by Sorex and those of Blarina are similar to Neomys. These findings confirm the opinion accepted by palaeontologists (Thenius \& Hofer, 1960) that the contemporary members of the family Soricidae, and especially those of the genera Sorex and Crocidura emerged last in the process of evolution.

Unfortunately, I had no specimens of the families Chrysochloridae, Tenrecidae and Solenodontidae at my disposal. The stomach of Eremitalpa granti, an African representative of the Chrysochloridae, examined by Allis on (1948), comes near to the stomachs of the Soricidae and Talpidae in many respects, which supports the hypothesis that this group of insectivores has common ancestors with shrews and moles (Thenius \& Hofer, 1960). The pyloric portion of the stomach of this mammal is unbent and elongated more or less as in the genus Crocidura. In addition, as in the Soricidae, the pyloric glands occupy a relati- 
vely large area in this species. The transition zone between the regions of pyloric and fundic glands is, however, very small, as in the Talpidae.

The differences observed in the shape and size of stomach within the Soricidae agree with the general evolutionary tendencies of this group. Irrespective of the generic and specific qualities of the Soricidae there are correlations between the body weight of these animals and their food requirements (Fig. 8) and between the amount of food eaten and the ambient temperature (M ezhzherin, 1964). Dehnel (1949, 1950) described the phenomenon of seasonal reduction in the height of brain-case in the genus Sorex and in Neomys. This process, later called "Dehnel's phenomenon", has been corroborated by many authors on very abundant material (see P u ce k, 1955, 1963). The reduction of the skull height in the shrews in the winter is accompanied by a drop in the weight of some internal organs (P u c e, 1965$)$ and that in the level of metabolism (Gębczyński, 1965). The occurrence of this general winter depression in the shrews should probably be related to the severe nutritional conditions in this season of the year, the more so, because a fall in the temperature of air makes it necessary for these animals to acquire much more food per unit of body weight. This thesis is also strengthened by the data presented by $\mathrm{Niethammer}$ (1956) and IM e zhzherin (1964), who found that in the northern populations of $S$. araneus and $S$. minutus there is a tendency towards a reduction of the body weight, as compared with the southern populations, and by observations published by Pucek (1963), who demonstrated the intensification of Dehnel's phenomenon (decrease in body weight and skull height) in the northern species of the genus Sorex as well as in the specimens of the same species living at lower mean annual temperatures. The lowering of the level of metabolism in shrews in the winter, in comparison with the summer findings, measured under laboratory conditions at a temperature of $20^{\circ} \mathrm{C}$, is relatively small (Gębczynski, 1965 ) and leads to only a slight decrease in their nutritional requirements. In the winter the temperature under snow, and so in the natural environment of shrews at that time, ranges from $0^{\circ} \mathrm{C}$ to $+5{ }^{\circ} \mathrm{C}(\mathrm{Coulia}$ $\mathrm{n}$ os \& J o hnels, 1962). This is a range of temperatures within which the Soricidae have the greatest food requirements (Mezhzherin, 1964). The mechanism which permits the shrews to meet the increased food requirements and, consequently, to live out this unfavourable season is the above-mentioned phenomenon of reduction of their body weight in the winter. Seasonal fluctuations of the stomach index observed in $S$. araneus may be regarded as an argument for this proposition. The absolute weight of the stomach does not undergo any changes, but its index is subject to remarkable and statistically significant 
fluctuations owing to changes in the body weight of animals. The absolute size of stomach does not change in the winter in spite of the increase of relative food requirements, probably because the drop in the body weight of shrews leads in the event to such a situation that the amount of food which must be acquired and digested, expressed in absolute units, is more or less the same throughout the year.

Bergman's rule cannot be applied to the contemporary shrews. The species of this group living in the Late Pliocene and Early Pleistocene had a small body size corresponding approximately to that of $S$. araneus. In the later periods, as the climate became colder, these animals, in Mezhzherin's opinion (1965a), grew bigger in accordance with Bergman's rule and reached the maximum size towards the end of the Middle or at the beginning of the Late Pleistocene. However, the growth of body weight brought about the necessity of consuming much larger amounts of food (in absolute units). The drop in temperature was followed, at least in some seasons, by the impoverishment of nutritional basis. Thus it came to the disturbance of balance in the organismenvironment relations. The redressment of the balance was achieved by the decrease in the body size of animals. This reasoning may be supported by the phenomenon discussed above of seasonal and geographical changes in the body weight of shrews, found in the contemporary forms. This character makes it, to some extent, possible for the shrews to extend to the north. However, this faculty for reduction of the body size of a given species is limited, which constitutes a strong barrier preventing a number of members of the Soricidae from extending their range further over colder territories. The encroachment of shrews on areas with a mean January temperature below $-30^{\circ} \mathrm{C}$ and even below $-40^{\circ} \mathrm{C}$ (north-eastern Siberia and Alaska) became possible with the emergence of species of very small size, represented, in the extreme case, by S. minutissimus (Mezhzherin, 1964, 1965).

The results obtained in the present investigations on the structure of stomachs in the Insectivora may be regarded as a confirmation of these evolutionary tendencies of the Soricidae. In comparison with Sorex the members of the genera Neomys and Crocidura have lighter and evidently less elongated stomachs and a smaller area of the mucous membrane per unit of body weight. At the same time, their range does not go so far to the north as that of the genus Sorex. When we come in turn to the genus Sorex, we find it evident that the greatest elongation of the stomach and, at the same time, the strongest development of the mucous membrane (in cu.cm per g of body weight) is typical of $S$. minutissimus, which is the smallest representative of this genus and inhabits the coldest territories within the range of the Insectivora. As has already been mentioned, 
this strong development of the stomach is asscciated with the necessity of digestion of a relatively larger amount of food in the same time. In this manner the shrews of small body size are able to satisfy their increased calorie requirements under severe thermal conditions.

Acknowledgment: Special acknowledgment is due for the valuable criticisms and suggestions made by Professor Zdzislaw $\mathrm{R}$ a abe and Dr. Zdzisław Pucek in the course of this work.

\section{REFERENCES}

1. Allis on A. C., 1948: The stomach in South African Insectivora, with notes on the organization of mammalian gastric gland. J. anat., 82, 4: 249-261.

2. Arnbäck-Christie Linde A., 1907: Der Bau der Soriciden und ihre Beziehungen zu anderen Säugetieren. Morph. Jahrb., 37, 4: 463-514.

3. B a b ock H. L., 1914: The food habits of the short-tailed shrew. Science, 40, 1032: $526-530$.

4. Bla gosklon ov K. N., 1957: O pitanii i haraktere sutočnoj aktivnostii krošečnoj burozubki (Sorex tscherskii O gn e v). Zool. Ż., 36, 3: 465-467.

5. Blos s o m P. M., 1932: A pair of long-tailed shrews (Sorex cinereus cinereus) in captivity. J. Mammal., 13: 136-143.

6. Butler P. M., 1948: On the evolution of the skull and the teeth in Erinaceidae, with special reference to fossil material in the British Museum. Proc. zool. Soc. Lond., 118: $446-500$.

7. Carlier E. W., 1893: Contribution to the histology of the hedgehog (Erinaceus europaeus). J. Anat. Physiol., 27: 85-111.

8. Christian J. J., 1950: Behavior of the mole (Scalopus) and the shrew (Blarina). J. Mammal., 31: 281-287.

9. Connaway C. H., 1952: Life history of the water shrew (Sorex palustris navigator). Amer. Midl. Nat., 48: 219-248.

10. Coulianos C. C. \& Johnels A. G., 1962: Note on the subnivean environment of small mammals. Ark. zool., Ser. 2, 15, 24: 363-370.

11. Dehnel A., 1949: Studies on the genus Sorex L. Annls Univ. M. Curie-Sklodowska, Sec. C., 4: 17-102.

12. Dehne1 A., 1950: Studies on the genus Neomys Ka up. Annls Univ. M. Curie-Skłodowska, Sec. C., 5: $1-63$.

13. Edelmann B., 1889: Vergleichende anatomische und physiologische Untersuchungen über eine besondere Region der Magenschleimhaut (Kardiadrüsenregion). Dtsch. Z. Tiermed. vergl. Path., 15: 155-214.

14. Flower W. H., 1872: Lectures on the comparative anatomy of the organs of digestion of the Mammalia. Med. Times Lond., 2: $1-2$.

15. G ębczyński M., 1965: Seasonal and age changes of metabolism and activity of Sorex araneus Linnae us, 1758. Acta theriol., 10, 22: 303-331.

16. Hamilt on W. J., 1930: The food of the Soricidae. J. Mammal., 11: 26-39.

17. Hauchecorne F., 1927: Ókolog.-biologische Studien über wirtschaftliche Bedeutung des Maulwurfs. Z. Morph. Ókol. Tiere, 9, 3/4: 439-571.

18. Hawkins A. E. \& Jewell P. A., 1962: Food consumption and energy requirements of captive british shrews and the mole. Proc. zool. Soc. Lond., 138: $137-155$.

19. Heptner J. G., 1939: The turkestan desert shrew, its biology and adaptive peculiarities. J. Mammal., 20: 139-149.

20. H is a w F. L., 1923: Feeding habits of moles. J. Mammal., 4: 9-20. 
21. Kostelecka-Myrcha A. \& Myrcha A., 1964: Rate of passage of foodstuffs through the alimentary tract of Neomys fodiens (Pen $n$ ant, 1771) under laboratory conditions. Acta theriol., 9: $371-373$.

22. M ezhzherin V. A., 1964: Javlenie Dehnela i ego vozmožnoe objasnenie. Acta theriol., 8, 6: 95-114.

23. Mezhzherin V. A., 1965a: O smene adaptacij v processe evoljucii (na primere roda Sorex, Insectivora, Mammalia). [Mat. zool. sovešč. po probleme: „Biologičeskie osnovy rekonstrukcii racionalnogo ispolzovanija i ohrany fauny južnoj zony evropejskoj častii SSSR']: 76-81. Kišinev.

24. M ezhzherin V. A., 1965b: Očerk četvertičnoj istorii i proishoždenija sovremennoj fauny zemleroek-burozubok (rod Sorex, Insectivora, Mammalia). Mat. po četvert. periodu Ukrainy (k VII Kongr. INQUA v SŠA): 164-174.

25. Morrison P. R., Pierce M. \& Ry ser F. A.. 1957: Food consumption and body weight in the masked and short-tailed shrews. Amer. Midl. Nat., 57: 493 -500 .

26. N a g e l e V., 1929: Uber Pylorus- und Duodenaldrüsen bei Insectivoren. Anat. Anz., 68, 6/10: 181-195.

27. Niethammer J., 1956: Das Gewicht der Waldspitzmaus Sorex araneus Li n n é, 1758 im Jahreslauf. Säugetierkd. Mitt., 4: 160-165.

28. Pernkopf E. \& Lehner J., 1937: Handbuch der vergleichenden Anatomie der Wirbeltiere. Ed. Bolk et al., Urban \& Schwartzenberg, Berlin.

29. Pucek Z., 1955: Untersuchungen über die Veränderlichkeit des Schädels im Lebenszyklus von Sorex araneus araneus L. Annls Univ. M. Curie-Skłodowska, Sec. C., 9, 4: 163-211.

30. Pucek Z., 1963: Seasonal changes in the braincase of some representatives of the genus Sorex from the Palearctic. J. Mammal., 44: 523-536.

31. Pucek Z., 1965: Seasonal and age changes in the weight of internal organs of shrews. Acta theriol., 10, 26: 369-438.

52. Rörig G., 1905: Über Nahrungsverbrauch einer Spitzmaus. Arb. Keiserl. Gesundh., 4: 121-122.

33. Simpson G. G., 1931: A new insectivora from the oligocene, Ulan Gochu horizon of Mongolia. Amer. Mus, Nov., 505: 22.

34. Skoczeń S., 1966: Stomach contents of the mole, Talpa curopaea Linnae u s, 1758 from Southern Poland. Acta theriol., 11, 28: 551-577.

35. Spiridonova K. A., 1949: Opyt rentgenovskogo issledovanija želudočno-kišečnogo trakta i fiziologii piščevarenija u krota (Talpa europaea L.). Zool. Ž., 28, 4: 382-384.

36. Springer S., 1937: Observations on Cryptotis floridana in captivity. J. Mammal., 18: 237-238.

37. Thenius E. \& Hofer H., 1960: Stammgeschichte der Säugetiere. Springer Verl.: $1-322$. Berlin.

38. Tupikova N. V., 1949: Pitanie i harakter sutočnoj aktivnosti zemleroek srednej polosy SSSR. Zool. Ž., 26, 6: $561-572$.

39. Vor ontzov N. N., 1962: The ways of food specialization and evolution of the alimentary system in Muroidea. Symp. Theriol. Brno 1960: 360-377.

Received, February 15, 1967.

Polish Academy of Sciences,

Mammals Research Institute,

Białowieża, woj. Białystok. 
Andrzej MYRCHA

BADANIA POROWNAWCZE NAD MORFOLOGIĄ ŻOEĄDKA U INSECTIVORA

\section{Streszczenie}

Przeprowadzone badania nad morfologią żołądków 27 gatunków owadożernych pozwalają stwierdzić, że ogólny plan budowy śluzówki żołądkowej wszystkich Insectivora jest podobny. U wszystkich gatunków można wyróżnić $\mathbf{5}$ dobrze wykształconych stref gruczołowych: obszary gruczołów wpustowych, dennych i pylorycznych oraz dwie strefy przejściowe (Tabela $1-3$, Ryc. $1-6$ ).

Względna wielkość żołądka owadożernych jest odwrotnie proporcjonalna do ich ciężaru ciała, co jest zapewne związane z większym u mniejszych gatunków zapotrzebowaniem pokarmowym. U mniejszych Insectivora obserwuje się powiększenie względnej powierzchni błony śluzowej żołądka, osiągane drogą zwiększenia obszaru gruczołów dennych oraz wydłużenia części pylorycznej tego narządu. Mechanizm ten doprowadza do zwiększenia się drogi i czasu działania enzymów proteolitycznych na pokarm białkowy. Absolutny ciężar i wielkość żołądka ryjówek nie podlega, występującej u nich, ogólnej depresji zimowej. Indeks żołądka natomiast zwiększa się wraz z obniżeniem. temperatury otoczenia, ponieważ $\mathrm{w}$ tym czasie zmniejsza się ciężar ciała zwierząt. Zimowe zwiększenie się indeksu żołądka ryjówek jest zapewne wyrazem obserwowanego $u$ nich $w$ niższych temperaturach wzrostu zapotrzebowania pokarmowego. Zmniejszenia rozmiarów ciała zapewnia więc możliwość zdobycia odpowiednich ilości pożywienia na jednostkę ciężaru ciała tych zwierząt. Najsilniejszym względnym rozwojem żołądka charakteryzują się gatunki najmniejsze, zamieszkujące zimniejsze tereny obszaru zajmowanego przez owadożerne (Tabele 4-6, Ryc. 7, 8). 